\title{
GEOLOGY OF METAPÁN VOLCANIC FIELD NW EL SALVADOR
}

\author{
Vladislav Rapprich ${ }^{1,2, *}$, Walter Hernández ${ }^{3, *}$, Vojtěch Erban ${ }^{1}$ \\ ${ }^{1}$ Czech Geological Survey, Klárov 3, 11821 Prague 1, Czech Rep. \\ ${ }^{2}$ Faculty of Science, Charles University, Albertov 6, 12843 Prague 2, Czech Rep. \\ ${ }^{3}$ Servicio Nacional de Estudios Territoriales, Km. 5 1/2 carretera a Santa Tecla y \\ Calle Las Mercedes, contiguo a Parque de Pelota. Edificio SNET, \\ San Salvador, El Salvador. \\ *Autores para contacto: rapprich@cgu.cz; whernandez@snet.gob.sv
}

(Recibido 16/02/06; aceptado 03/11/06)

\begin{abstract}
Metapán volcanic field occupies the eastern margin of the Ipala Graben and represents one of several 'Behind volcanic front' type fields in El Salvador. It was subdivided into four zones in regard to the distinct age and location of each of them. The duration of the volcanic activity in the Metapán area has been from Pliocene to Quaternary. The volcanism started with the formation of the El Cóbano shield-volcano in the SE part of the study area, which is preserved as a relict of a sequence of basaltic lavas, approximately $300 \mathrm{~m}$ thick. Later volcanic activity represented by Strombolian cones, Hawaiian fissure vents and lava fields took place in three separated areas: El Shiste to the northwest, Ostúa to the west and San Diego to the south of the Metapán town. All studied volcanic events in this area are older than the last Plinian eruption of Ilopango caldera, which produced tephra of Tierra Blanca Joven (TBJ: 430 AD).

Key words: El Salvador, Metapán, San Diego, El Shiste volcano, 'behind-volcanic-front' volcanism, volcanostratigraphy, Ipala Graben.
\end{abstract}

RESUMEN: El área volcánica de Metapán ocupa el margen oriental del Graben de Ipala y representa uno de varios campos volcánicos detrás del frente volcánico de El Salvador. Este campo ha sido dividido en cuatro zonas de acuerdo con la edad y la localización de cada uno. La actividad volcánica en el área de Metapán varía desde el Plioceno hasta el Cuaternario. La actividad comenzó con la formación del volcán El Cóbano que representa un relicto de un volcán en escudo en la parte SE del área de estudio, con una secuencia de lavas basálticas de aproximadamente $300 \mathrm{~m}$ de espesor. La actividad volcánica posterior está representada por conos estrombolianos, erupciones fisurales tipo hawaiano y campos de lavas que tuvieron lugar en tres áreas separadas: El Shiste en el noroeste, Ostúa en el oeste y San Diego al sur de la ciudad de Metapán. Todas las emisiones volcánicas estudiadas son más antiguas que la última erupción pliniana de la Caldera Ilopango, que ha producida las tefras Tierra Blanca Joven (TBJ: 430 D.E.).

Palabras clave: El Salvador, Metapán, San Diego, El Shiste volcán, volcanismo 'behind-volcanic-front', estratigrafía volcánica, Ipala Graben. 


\section{INTRODUCTION}

The volcanism in Central America is associated with the subduction of the Cocos plate beneath the Caribbean plate (Mann ed., 1995 and references therein). It is situated in two contrasting geotectonic settings: (1) The dominant volcanic front (VF), represented by major stratovolcanoes, located directly above the subduction zone not more than $200 \mathrm{~km}$ from the trench, and (2) more distant, an irregular zone of volcanic edifices formed in the so called 'behind volcanic front' setting (BVF) (Walker, 1981). The latter volcanic zone was documented in southern Guatemala, El Salvador, SW Honduras and NW Nicaragua. It is characterized by the presence of small, basaltic volcanic forms, mostly monogenic cinder cones and associated lava fields, smaller shield volcanoes are less abundant. The BVF volcanics cluster chiefly in domains of extensional tectonic regime, oriented perpendicular to the main volcanic front. The most prominent extensional structure is the Ipala Graben, situated in southeastern Guatemala and northwestern El Salvador. The current study is focused on the area surrounding the town of Metapán in NW El Salvador (Fig. 1) on the eastern border of the Ipala Graben (Fig. 2).

With respect to the economic potential, the interest in the region of El Salvador-GuatemalaHonduras triple junction was primarily focused on the Cretaceous sedimentary sequences with exploitable limestone layers (Weber, 1979 and references therein), whereas small volcanic forms in this region were mentioned only briefly. Williams \& Meyer-Abich (1955) studied the volcanic chain and coastal zone of El Salvador. They published several observations from the vicinity of Chalchuapa, at the southern end of the Ipala Graben. However, the Quaternary basaltic volcanism of the Metapán volcanic field was beyond the scope of their paper. Moreover, they failed to recognize the specific BVF character of scattered cinder cones in this region.

A pioneering study of the Ipala Graben geology was performed by Williams et al. (1964). They singled out the north-south aligned volcanic forms of the Ipala Graben from the chain of composite volcanoes aligned in a northeastsouthwestern direction, parallel to the Middle America Trench. As their work was focused on the Guatemalan part of the Ipala Graben, they only indicated briefly the north-south alignment of the cones between Lakes Güija and Metapán in El Salvador. Carr $(1974,1976)$ for the first time presented major and selected trace element data from the Ipala Graben volcanics. Following studies questioned the geotectonic position and petrogenetic processes involved in the generation of BVF magmas in SE Guatemala and SW Honduras (areas of Tegucigalpa and Yojoa Lake)(Walker, 1981; Walker et al., 1995 and 2000; Patino et al., 1997; Carr et al., 2003). The complete set of geochemical data from Central American volcanoes collected by M. Carr and his co-workers is available online at http://www-rci. rutgers.edu/ carr/index.html.

The studied area was, as a part of the Salvadorian territory, covered by a mapping project of the German expedition in 1967-71 (Weber et al., 1974; Wiesemann et al., 1978). Their work, encompassing the entire El Salvador, enabled understanding of large-scale relations among defined formations, but brought no new knowledge on local geology. In 2005 a new geological map on a scale 1:50 000 of Metapán and its surroundings was carried out by a team of the Czech Geological Survey (Hradecký et al., 2005). The lavas and cinder cones of Cinotepeque range, comparable to the Metapán volcanic field, were briefly described by Rapprich \& Hradecký (2005).

\section{STRATIGRAPHY}

The Metapán volcanic field is subdivided into four zones according to their relative ages and locations (Fig. 2). These are listed in stratigraphic order from the oldest to the youngest (letters in parentheses correspond to Fig. 2):

-The oldest - El Cóbano shield volcano (d)

-The northernmost - El Shiste zone (c)

-Ostúa zone on the west (b)

-The youngest - San Diego zone (a) 


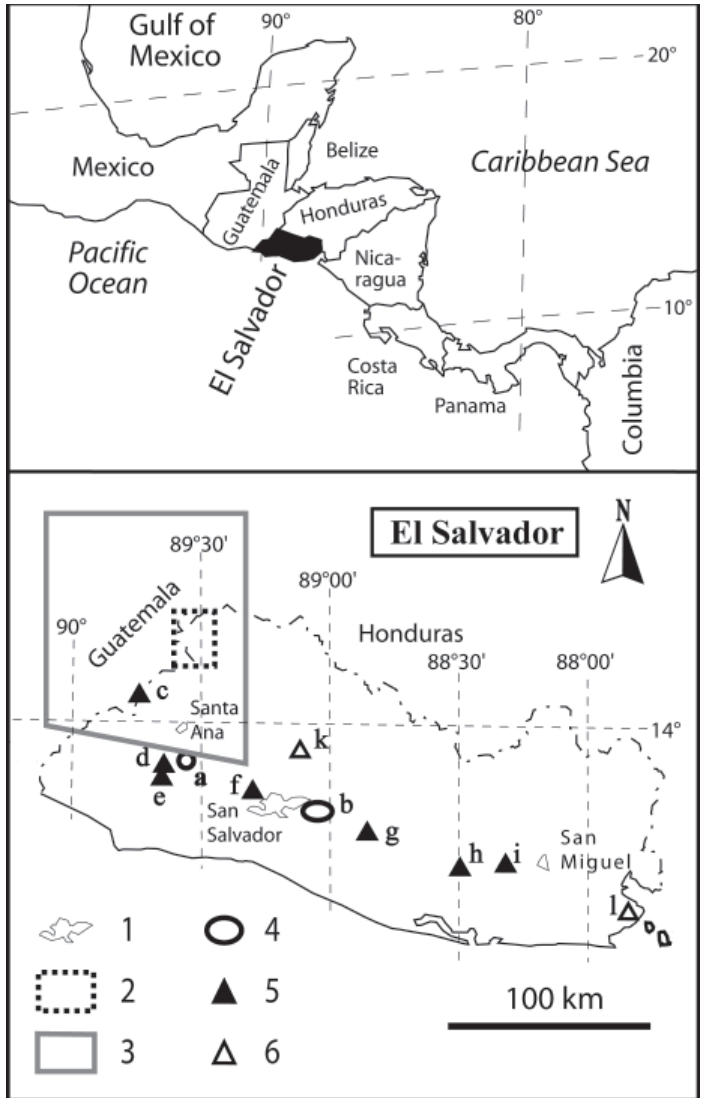

Fig. 1: Location of the study area (adapted after Rapprich \& Hradecký, 2005). 1 - principal cities; 2 - limits of the study area; 3 - approx. limits of Fig. 2.; 4 - major calderas: a - Coatepeque, b - Ilopango; 5 - large composite volcanoes: c - Chingo, d - Santa Ana, e - Izalco, f - San Salvador, g - San Vicente, h - Usulután, i - San Miguel; 6 - extinct volcanoes: $\mathrm{k}$ - Guazapa, 1 - Conchagua.

\section{San Diego zone}

The most important zone of the Metapán volcanic field is the zone of San Diego (Fig. 3). It is delimited by the San Diego fault and the relatively uplifted El Cóbano lavas on the east, Güija Lake on the west and Metapán Lake on the north. The volcanics of this zone filled the tectonic valley of the San Diego fault. Hradecký et al. (2005) divided the volcanic rocks of this zone into two formations. Older and mostly strongly weathered olivine basaltic lavas and scoriae of the Pre-San Diego Formation outcrop below the younger and fresh lavas of the San Diego Formation, which consist also of olivine basalts. The volcanics of
Pre-San Diego occur in "windows" and are not covered by younger volcanic products. The most prominent cone of the Pre-San Diego formation is the relict of La Vega de la Caña Antigua cinder cone on which sits the younger and smaller La Vega de la Caña Joven (Fig. 3). To the north of La Vega de la Caña is preserved a tuff ring relict, now buried by younger lavas, evidence of the phreatic eruption of a maar. Another small, unnamed cinder cone of the Pre-San Diego Formation occurs northeast of La Vega de la Caña. This cone dammed a younger lava flow from Loma Iguana and disabled this lava to cover gravels of the Valle Capulín Formation. A depression south of the unnamed cinder cone, where Valle Capulín gravels are exposed, is delimited by faces of lavas from various sources. Another remnant of the Pre-San Diego Formation is located about $1 \mathrm{~km}$ east of Punta Brava. A Hawaiian spatter cone was destroyed by slope deformations on the gravel plateau of the Santa Rosa or Valle Capulín Formation (the alluvial formations were described in Hradecký et al., 2005). Several occurrences of Pre-San Diego lavas can be found on the foothills around the San Diego volcano (Fig. 3).

Lavas of the younger San Diego Formation came from several vents. The dominant peak and the highest volcano of the area is San Diego. Its youngest lava flow covers the central part of the studied area. The effusion of the lava was limited by the escarpment of San Diego Fault on the east (Figs. 2 and 3). The San Diego volcano cone has been formed by at least two events. The older one produced a relatively flat cone with a crater probably opened to the south. The rest of the original crater rim is preserved on the northern flank of the San Diego volcano. The younger event was characterized by Strombolian activity, which built a steep cone. Fine yellow scoria covering the area from Cerro Quemado to the town of Metapán was produced also by this younger event. The younger cone buried most of the original cone, including the lava vent and channel.

The area NW from San Diego volcano is covered by another young lava flow. It remains unclear if this lava was produced only from Cerro 


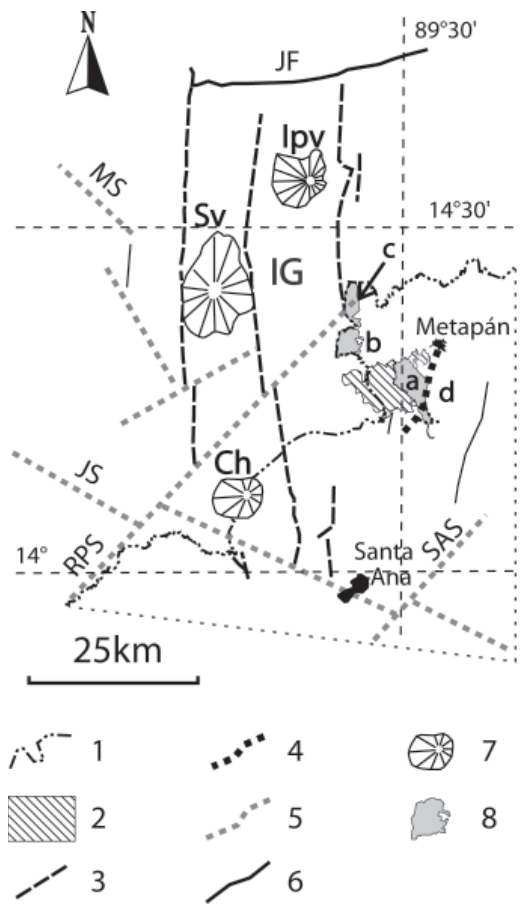

Fig. 2: Relation of the Metapán volcanic fields to the structure of Ipala Graben (adapted after Carr, 1974 and Hradecký et al., 2005). 1 - border between Guatemala and El Salvador; 2 - Lakes of Güija and Metapán; 3 - major faults of the Ipala Graben (IG); 4 - San Diego fault; 5 - major shear zones (Monjas Shear - MS, Jalpataqua Shear - JS, Río Paz Shear zone - RPS and Santa Ana Shear zone - SAS); 6 - Jocotán fault; 7 - major volcanoes of the Ipala Graben (Ipala volcano - Ipv, Suchitán volcano - Sv and Chingo - Ch); 8 - individual zones of the Metapán volcanic field: a - San Diego, b - Ostúa, c - El Shiste, d - relict of El Cóbano shield-volcano.

Las Iguanas or if it is a combination from two sources: Cerro Las Iguanas and Loma Iguana. Cerro Las Iguanas is a small, $80 \mathrm{~m}$ high cinder cone of Strombolian origin with a crater and lava channel oriented to the west, whereas the Loma Iguana is a Hawaiian fissure vent located at a fault-crossing. This fault-crossing consists of a $\mathrm{N}-\mathrm{S}$ trending fault, dextrally displacing (about $300 \mathrm{~m}$ ) an older NW-SE trending fault.

Masatepeque cinder cone is located between San Diego and Cerro Iguana volcanoes. This Strombolian cone, comparable with Cerro Iguana in size, produced a relatively small lava flow approximately $2 \mathrm{~km}$ wide and $1 \mathrm{~km}$ in length.

Punta Brava peninsula in the Metapán Lake is made up of a lava flow produced from a more complex Hawaiian source, which consists of several scoria rings and crescents (Fig. 3).

The youngest cinder cone of this zone is Cerro Quemado on the south. Its lava is younger than the youngest lava of San Diego, as inferred from spatially limited superposition of both lavas, and differences in degree of weathering and vegetation. A sequence of pyroclastic deposits was documented on the foothill of the Cerro Quemado (Fig. 4). The lava of Cerro Quemado is covered by coarse basaltic Strombolian scoriae of Cerro Quemado cinder cone (Fig. 5). During the magma ascent to the surface pumice fragments were captured from the basement of the cinder cone, which appear now as xenoliths within the scoriae. The products of Cerro Quemado are overlain by fine yellow scoria of the last eruption of San Diego. The entire sequence is crowned with very fine ashes of distal fall-out deposits of Tierra Blanca Joven, produced by the last eruption of the Ilopango caldera (430 AD, Dull et al., 2001). As no younger volcanic products have been found in the San Diego zone, all the eruptions presumably took place before $430 \mathrm{AD}$. The Cerro Quemado and San Diego yellow scoria may be inferred to be of Latest Pleistocene or Early Holocene in age, based on they preserved primary morphology and the absence of weathering products. These were found neither on proper cones (from where these may have been washed by rainfall) nor among sub-horizontally layered successions excavated by human activities (quarries, constructions).

\section{Ostúa zone}

The Ostúa zone is situated to the south of the El Shiste field (Fig. 2: b). It consists of two main cinder cones (Cerro de Ostúa and Cerro La Culebra), formed by Strombolian eruptions, and a NE-SW oriented Hawaiian fissure vent (Loma La Culebra). These volcanic vents produced a lava plateau covering approximately $16 \mathrm{~km}^{2}$ on Salvadorian territory and continuing to Guatemala. The Cerro La Culebra cone rests on relicts of two older Hawaiian to Strombolian cones, which crop out on the southern foothill of the Cerro La Culebra. In contrast with rather 


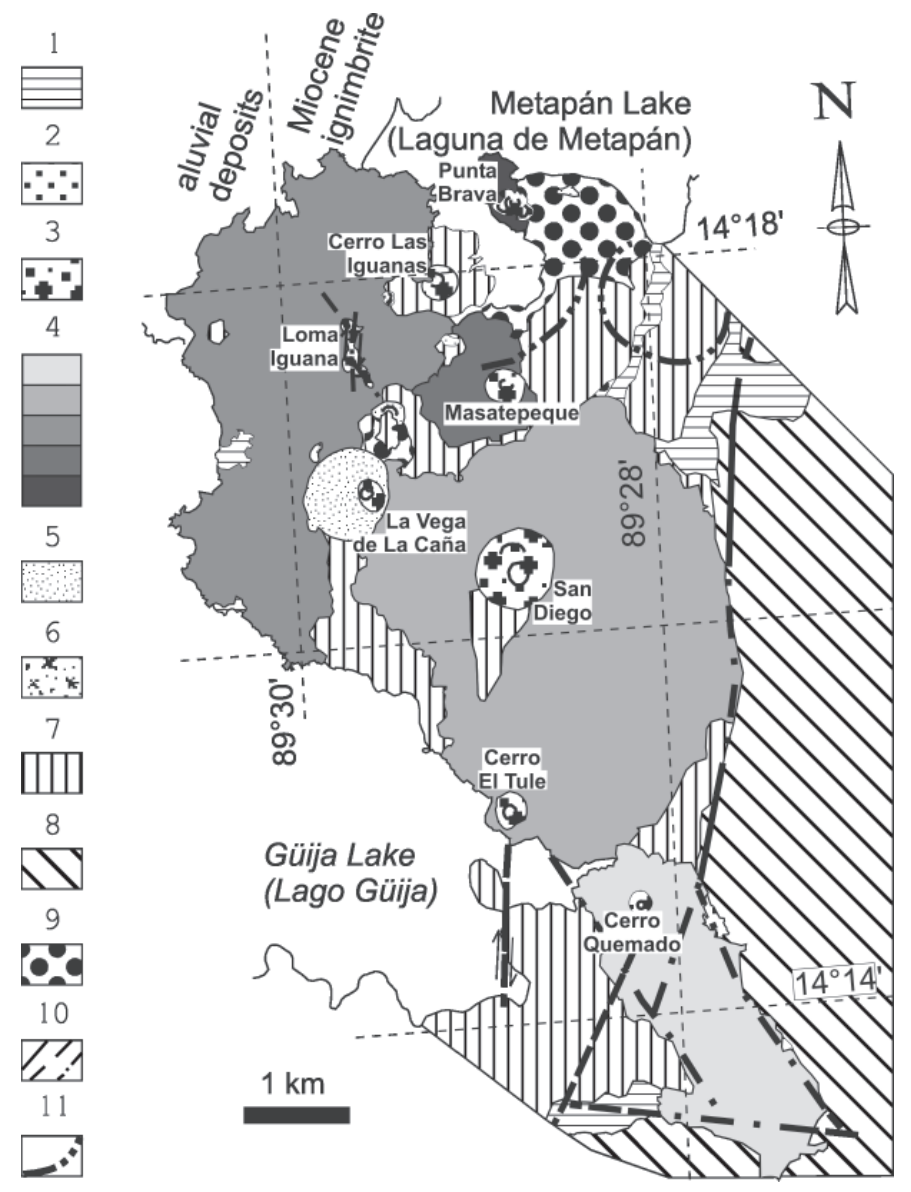

Fig. 3: Detailed volcanological map of the San Diego area (modified after Hradecký et al., 2005). 1) colluvial and fluvial deposits; 2) TBJ fall out; 3) scorias of San Diego formation; 4) lavas of San Diego Formation: Cerro Quemado/San Diego/Iguana/ Masatepeque/Punta Brava; 5) scoriae of Pre-San Diego Formation; 6) maar sequence (Pre-San Diego); 7) lavas of Pre-San Diego Formation; 8) lavas of El Cóbano; 9) alluvial gravels of Santa Rosa and Valle Capulín formations; 10) fault verified/supposed/ covered by younger volcanics and sediments; 11) subsidence structures of San Diego.

weathered scoriae of Cerro La Culebra and Loma La Culebra, both covered by vegetation, the scoria cone Cerro Ostúa shows low degree of weathering and scarce vegetation (Fig. 6). Therefore, a Holocene age of the Cerro de Ostúa is supposed. Loma La Culebra fissure vent rests on a NE-SW oriented fault.

\section{El Shiste zone}

The northernmost occurrence is situated in the surroundings of El Shiste village, about 17 km NW from Metapán (Fig. 2: c). Basaltic products of El Shiste are overlying Miocene rhyolitic ignimbrites of the Chalatenango or Morazán formations (Wiesemann et al., 1978). As the selective erosion already took place, only lava flows and compact vent-fillings are preserved. Relicts of scoriaceous agglutinates are preserved on the rims of these vents. Fall out scoriae preserved between lava flows are exposed occasionally in the road cuts, for example on the road Caserío Matalapa - Sitio El Manguito, about $13 \mathrm{~km}$ west of Metapán. Here, a $20 \mathrm{~cm}$ thick layer of fall out scoria separates two relatively fresh basaltic lava flows overlying older weathered basaltic lavas 


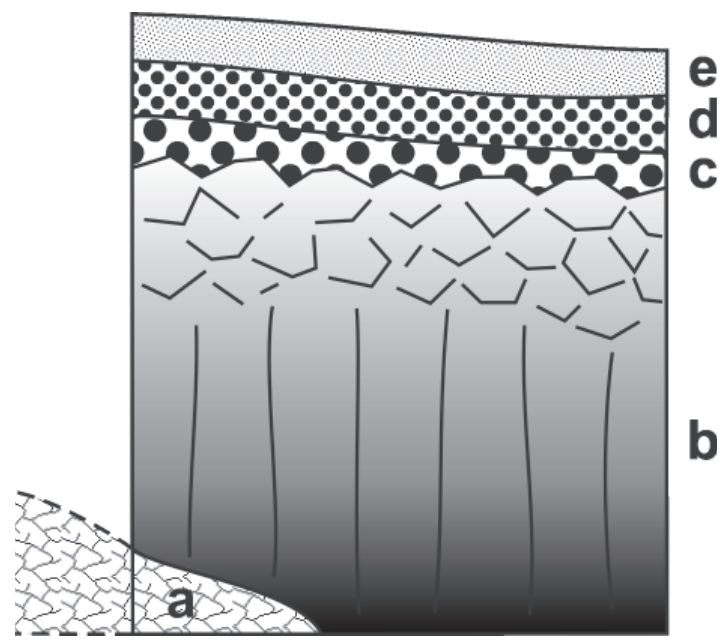

Fig. 4: Stratigraphic relations of Holocene volcanics of the San Diego area. a) the youngest lava of San Diego volcano; b) lava Cerro Quemado with c) dark scoriae; d) yellow scoriae of San Diego; e) distal fall out ashes of Ilopango caldera (Tierra Blanca Joven - TBJ).

and Miocene rhyolitic ignimbrites (Fig. 7). The basaltic fresh-looking lava (El Shiste) was dated by the K-Ar method (whole-rock) at $2.77 \pm 0.11$ Ma (Hradecký et al., 2005).

\section{El Cóbano zone}

The relict of El Cóbano shield volcano represents probably the oldest products of the back-arc activity of the Metapán volcanic field. Basaltic lavas with individual thickness of $2 \mathrm{~m}$ separated by $2 \mathrm{~m}$ thick layers of autoclastic breccias (Fig. 8) build a 300-400 m thick sequence. The shield volcano is cut by the N-S trending San Diego fault. The western block subsided at least $300 \mathrm{~m}$ with respect to the eastern block. The lava sequence is best exposed on the fault slope, whereas on the surface of the shield volcano the lavas are strongly weathered (Fig. 9). As the tectonics and erosion strongly modified the shape of this shield volcano, volcanological interpretations, such as determination of source vents or lava flow directions, are impossible. Peaks of El Tepeto (872 m a.s.l.), El Cóbano (788 m a.s.1.) and Cerro Conchagua (744 $\mathrm{m}$ a.s.1.) with their rugged morphology may represent remnants of the original conduits.

\section{TECTONIC SETTING}

Oblique subduction on the Central American Trench pushes the Chortis block along the Motagua-Chamalecon fault system to the east (left-lateral movements - Burkart \& Self, 1985; Martínez-Díaz et al., 2004). Right-lateral movement in the Median Trough was documented by several authors (Dengo et al., 1970; MartínezDíaz et al., 2004; Williams \& Meyer-Abich, 1955; Williams et al., 1964). Such eastward migration resulted in an extensional regime of Central America south of the Motagua and Jocotán faults and the formation of the N-S trending grabens and horsts.

Stoiber \& Carr (1973) and Carr (1976) subdivided the Central American Trench into several segments according to the interpretation of seismic data. The Salvadorian segment is characterized by a steeper angle of the seismic zone tracing the subduction path. Therefore, in El Salvador the volcanic front is closer to the trench than in Guatemala (Burkart \& Self, 1985). Principal grabens (Ipala, Comayagua and also Guatemala City Graben) rest on the discontinuities between individual segments.

The Ipala Graben is nearly perpendicular to the Salvadorian Central Graben (or The Median Trough by Williams \& Meyer-Abich, 1955; or Central Depresion by Dengo et al., 1970, respectively) and is parallel to the N-S trending Comayagua Graben (Williams et al., 1964) and

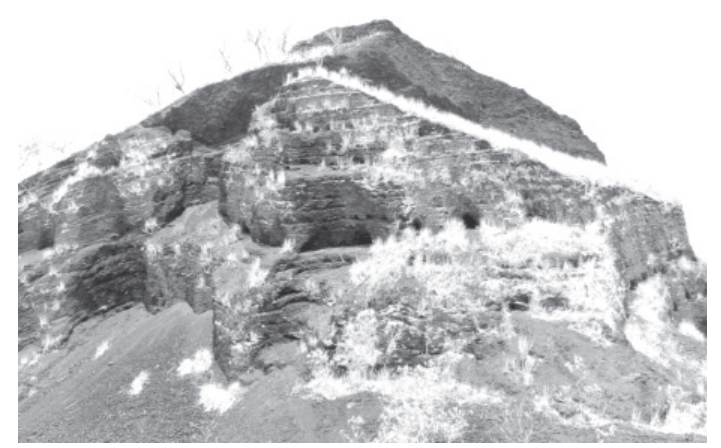

Fig. 5: Well outward bedded scoriae of the Cerro Quemado cinder cone. Abandoned quarry for scoria exposed this outcrop. Stratification and absence of welding suggest a Strombolian eruption style. 
the horst of the Cinotepeque range (Rapprich \& Hradecký, 2005). The Central Graben in El Salvador is oriented approximately E-W that differs from approximately NW-SE orientation of the Nicaraguan Depression east of the Fonseca Gulf (located in the southern prolongation of the Comayagua Graben; Sapper, 1937). Right-lateral movements documented on some faults of the studied area (Fig. 3) may suggest the character of Riedel shears related to the right-lateral motions on the Salvadorian Central Graben.

The San Diego Fault represents the lateral shoulder of the Ipala Graben (Fig. 2) with documented subsidence of the western block reaching some $300 \mathrm{~m}$. Volcanic activity of BVF forming El Cóbano shield volcano started before the main movements on the San Diego Fault and the fault later cut the shield volcano. Later volcanic activity (Pre-San Diego and San Diego formations) partly filled the tectonicallycreated valley.

The N-S alignment of the vents of the San Diego Formation suggest they are related to tectonic lines parallel to the San Diego Fault (Fig. 5; Williams et al., 1964 noted this fact as well). On some segments of these N-S trending faults, dextral throws are well visible. These right-lateral motions affected lavas of the Pre-San Diego Formation, but did not disturb the lavas of the San Diego Formation. The fissure vent of Loma Iguana is located on a fault-crossing, as stated before.

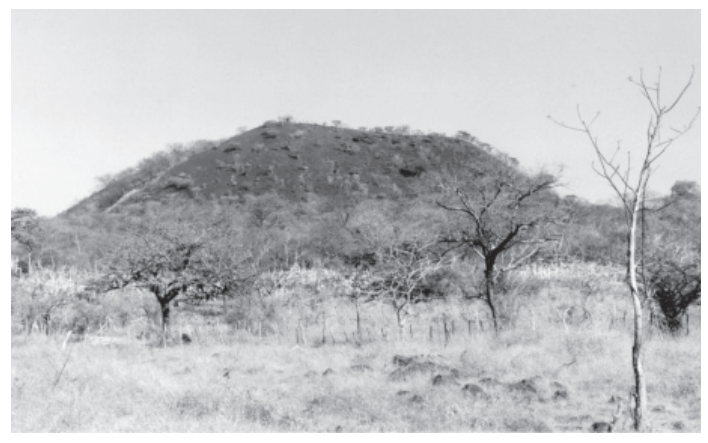

Fig. 6: Cinder cone of the Cerro de Ostúa with fresh shape and lack of vegetation.

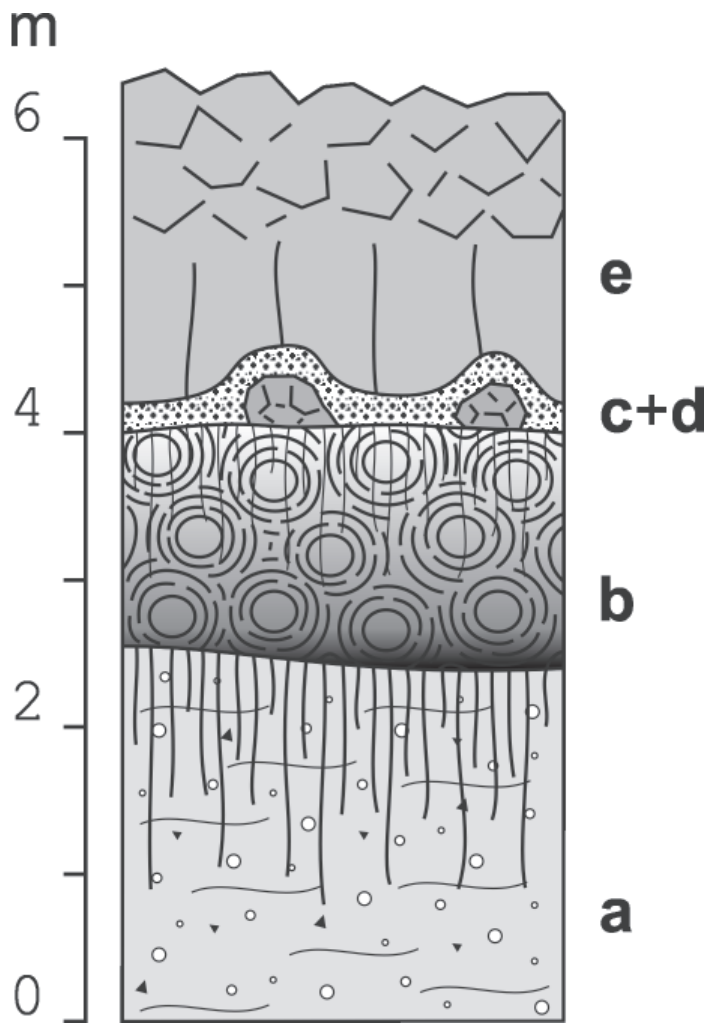

Fig. 7: Stratigraphic column of the sequence of El Shiste exposed by the road cut at Matalapa (after Hradecký et al., 2005 - point 254). a) Paleosoil and weathered rhyolitic Miocene ignimbrite; b) palaeosoil and weathered basaltic lava (more ancient activity of El Shiste); c) blocks of fresh basaltic lava; d) scoriaceous fall-out deposit of a Strombolian eruption; e) fresh basaltic aa-lava (Pliocene).

The Ostúa and El Shiste volcanic zones rest on relatively stable blocks on the eastern margin of the Ipala Graben. Some N-S alignments of volcanic vents can be observed as well.

\section{San Diego subsidence structures}

North of the San Diego volcano (Fig. 3) two circular subsidence structures occur. These were mostly interpreted as volcanic craters (maars or small calderas; Williams et al., 1964, Wiesemann et al., 1978), but there were observed no deposits 


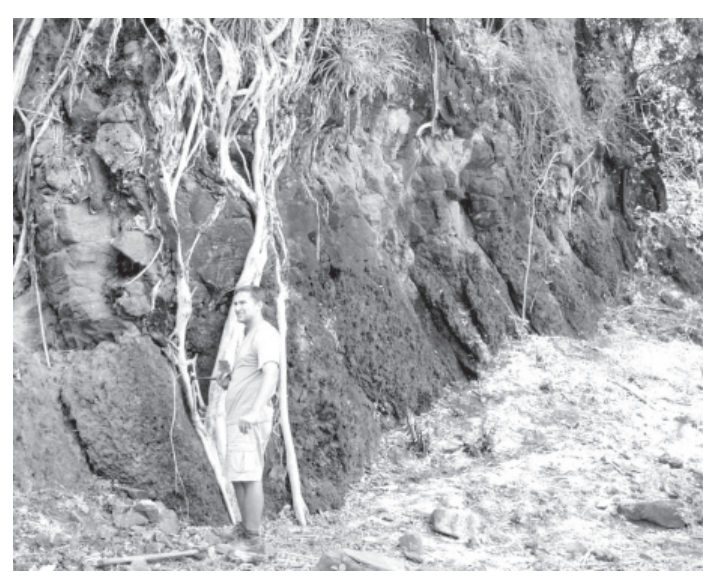

Fig. 8: Alternation of compact lava facies and autoclastic breccia facies exposed on the San Diego fault slope in El Cóbano shield volcano (photo by T. Vorel).

of either magmatic or phreatic activity related to the formation of these structures. A system of concentric subsidence ring faults creates them and their inner part consists of solid basaltic lava - the same as in surroundings. Neither phreatic eruption nor cauldron subsidence may explain these structures. On the other hand, hypotheses relating the subsidence to karst or pseudokarst processes in the underlying sedimentary sequences (Tertiary or Cretaceous, cropping not far away) cannot be ruled out. However, the hypothesis could be hardly proven in absence of borehole or geophysical data.

\section{CHEMICAL COMPOSITION OF LAVAS}

Four rock samples of representative lava flows from the studied area were analyzed in the laboratories of the Czech Geological Survey in Prague (Table 1). Major and trace elements were determined using FAAS and XRF techniques. Geochemical data were evaluated using the software GCDkit (Janoušek et al., 2006).

All analyzed basalts are similar in petrography. Phenocrysts are represented by plagioclase $\left(\mathrm{An}_{74-79}\right)$ and clinopyroxene, Fe-Ti oxides in the matrix are common. Minor olivine ( $\left.\mathrm{Fo}_{80}\right)$ does occur, but is abundant only in the sample 242, being decomposed. Fresh olivines were observed in many lavas of the studied area, during field campaign.

According to the TAS diagram (Le Bas et al., 1986), the lavas are classified as basaltic andesites to basaltic trachyandesites (Fig. 10). Other samples from the Metapán area, published by Carr (1974), also show basaltic composition. The studied rocks, as well as those from the Ipala Graben (Carr, 1974) and Cinotepeque range (Rapprich \& Hradecký, 2005), are of subalkaline character, following the Calc-alkaline trend, which corresponds to the relatively low $\mathrm{Fe}$ content (Fig. 11). In the silica vs. $\mathrm{K}_{2} \mathrm{O}$ plot, the analyses correspond mainly to the normal calcalkaline series, in transition to the high-K calc-alkaline series (Fig. 12) (Pecerillo \& Taylor, 1976).

The Ni content varies between 20 and $52 \mathrm{ppm}, \mathrm{Cr}$ between 62 and 122, the $\mathrm{Mg \#}$ $\left[\mathrm{Mg} /\left(\mathrm{Mg}+\mathrm{Fe}^{2+}\right)\right]$ falls within the range 0.58 0.68 . These values are higher than in the majority of the volcanic front lavas, similar to the BVF products of Guatemala and El Salvador (Walker et al., 2000; Rapprich \& Hradecký, 2005), but still far away from a primary melt composition. Also various incompatible and fluid immobile elements, such as $\mathrm{Nb}$ and $\mathrm{Y}$, show higher contents than in the VF products. This is shown in figure 13, where our data match the BVF characteristics according to Walker et al. (2000). Similar rocks from central El Salvador (Rapprich \& Hradecký, 2005) are plotted for comparison.

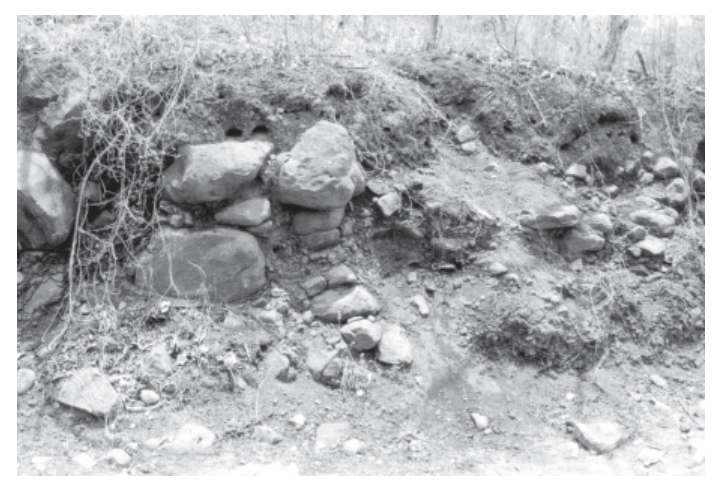

Fig. 9: Strongly weathered basaltic lavas on the apical plateau of the El Cóbano shield-volcano. 


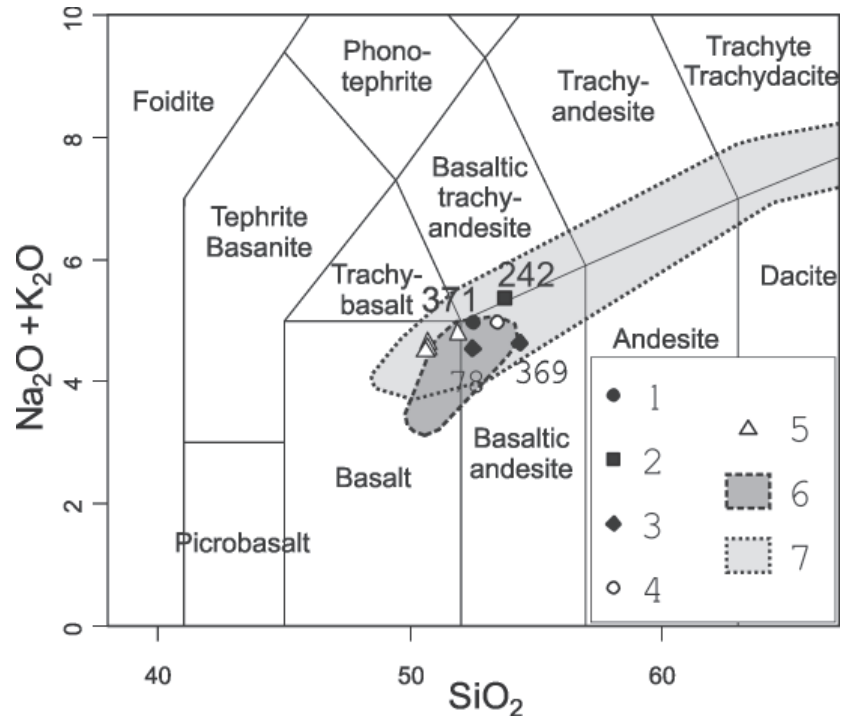

Fig. 10: TAS diagram (Le Bas et al., 1986) of the analyzed lavas from surroundings of Metapán town. 1) lava of Cerro Quemado (sample 371); 2) El Shiste (sample 242); 3) lavas of El Cóbano shield volcano (samples 78 \& 369); 4) lava of Cerro Quemado; 5) lavas of San Diego volcano; 6) compositional range of BVF basalts from the Cinotepeque range; 7) compositional range of volcanics from entire Ipala Graben ( 1 - 3 data from Hradecký et al., 2005; 4, 5 and 7 data from Carr, 1974; 6 data from Rapprich \& Hradecký, 2005).

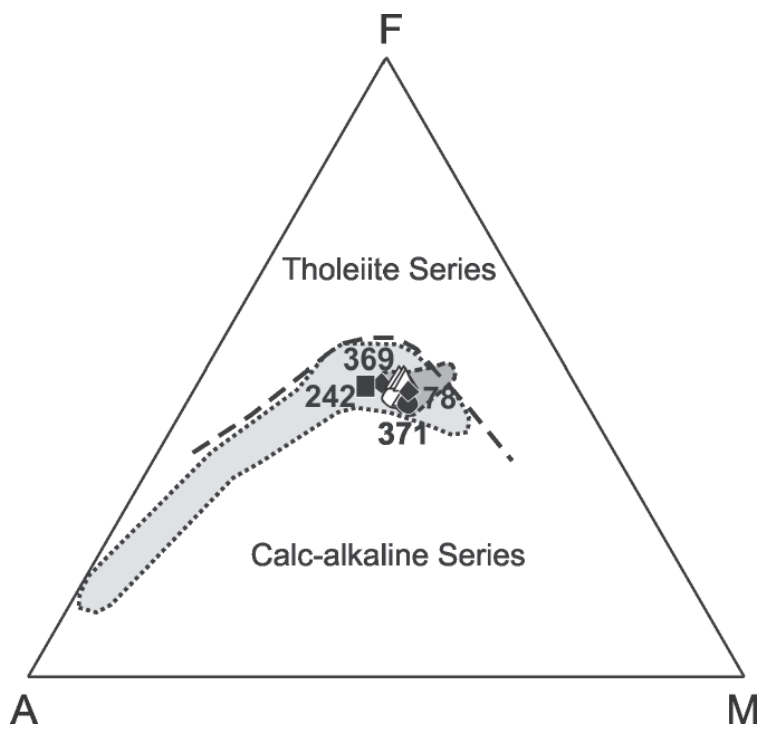

Fig. 11: AFM diagram (Irvine \& Baragar, 1971). Symbols correspond to those in Fig. 10.

Analogous volcanic products from the Guatemalan part of the Ipala Graben were described in detail by Walker et al. (2000). Taking into account the limited amount of available geochemical data, there seems to be no marked difference between the volcanics of Metapán area and the rest of the Ipala Graben. Therefore, we can adopt the conclusions of Walker at al. (2000), who argued for a principal role of mantle decompression melting. 
Table 1

Chemical analyses of basaltic rocks from the Metapán volcanic field (from Hradecký et al., 2005)

\begin{tabular}{|c|c|c|c|c|}
\hline \multirow{2}{*}{ Location } & 78 & 242 & 369 & 371 \\
\hline & Metapán & El Shiste & El Cóbano & Cerro Quemado \\
\hline North & $14^{\circ} 19^{\prime} 15^{\prime \prime}$ & $14^{\circ} 24^{\prime} 21^{\prime \prime}$ & $14^{\circ} 14^{\prime} 24^{\prime \prime}$ & $14^{\circ} 14^{\prime} 03^{\prime \prime}$ \\
\hline West & $89^{\circ} 27^{\prime} 21^{\prime \prime}$ & $89^{\circ} 34^{\prime} 26^{\prime \prime}$ & $89^{\circ} 27^{`} 26^{\prime \prime}$ & $89^{\circ} 27^{`} 41^{\prime \prime}$ \\
\hline $\mathrm{SiO}_{2}$ & 51.71 & 53.3 & 52.39 & 52.18 \\
\hline $\mathrm{TiO}_{2}$ & 0.99 & 1.08 & 0.99 & 1.19 \\
\hline $\mathrm{Al}_{2} \mathrm{O}_{3}$ & 17.21 & 17.66 & 17.08 & 17.03 \\
\hline $\mathrm{Fe}_{2} \mathrm{O}_{3}$ & 3.23 & 3.43 & 4.64 & 2.67 \\
\hline $\mathrm{FeO}$ & 5.78 & 5.42 & 3.64 & 6.29 \\
\hline $\mathrm{MgO}$ & 5.65 & 4.27 & 4.23 & 6.11 \\
\hline $\mathrm{CaO}$ & 9.06 & 8.06 & 8.43 & 8.38 \\
\hline $\mathrm{MnO}$ & 0.169 & 0.154 & 0.133 & 0.168 \\
\hline $\mathrm{SrO}$ & 0.066 & 0.072 & 0.037 & 0.053 \\
\hline $\mathrm{BaO}$ & 0.069 & 0.086 & 0.038 & 0.044 \\
\hline $\mathrm{Li}_{2} \mathrm{O}$ & 0.002 & 0.002 & 0.002 & 0.002 \\
\hline $\mathrm{Na}_{2} \mathrm{O}$ & 3.12 & 3.64 & 3.12 & 3.56 \\
\hline $\mathrm{K}_{2} \mathrm{O}$ & 1.36 & 1.68 & 1.34 & 1.36 \\
\hline $\mathrm{P}_{2} \mathrm{O}_{5}$ & 0.259 & 0.453 & 0.345 & 0.403 \\
\hline F & 0.059 & 0.04 & 0.053 & 0.057 \\
\hline $\mathrm{CO}_{2}$ & 0.042 & $*$ & 0.24 & 0.01 \\
\hline $\mathrm{C}$ & 0.014 & 0.008 & 0.012 & 0.01 \\
\hline $\mathrm{H}_{2} \mathrm{O}^{+}$ & 0.81 & 0.39 & 1.94 & 0.48 \\
\hline $\mathrm{H}_{2} \mathrm{O}^{-}$ & 0.14 & 0.16 & 1.22 & 0.08 \\
\hline Total & 100.11 & 99.91 & 99.88 & 100.09 \\
\hline Be (FAAS) & 2.2 & 2.4 & 2.1 & 2.8 \\
\hline Co (FAAS) & 30 & 26 & 29 & 30 \\
\hline $\mathrm{Cu}$ (FAAS) & 55.5 & 44.4 & 53.8 & 45.6 \\
\hline $\mathrm{Cr}(\mathrm{XRF})$ & 78 & 62 & 67 & 122 \\
\hline Ni (XRF) & 26 & 20 & 34 & 52 \\
\hline $\mathrm{Cu}(\mathrm{XRF})$ & 51 & 43 & 51 & 41 \\
\hline $\mathrm{Zn}(\mathrm{XRF})$ & 77 & 91 & 87 & 79 \\
\hline $\mathrm{Rb}(\mathrm{XRF})$ & 20 & 21 & 19 & 16 \\
\hline $\mathrm{Sr}$ (XRF) & 495 & 513 & 481 & 497 \\
\hline $\mathrm{Zr}(\mathrm{XRF})$ & 137 & 234 & 179 & 191 \\
\hline $\mathrm{Nb}(\mathrm{XRF})$ & 5 & 12 & 7 & 8 \\
\hline $\mathrm{Y}(\mathrm{XRF})$ & 23 & 31 & 27 & 30 \\
\hline
\end{tabular}

K-Ar age (Ma) $\quad$ - $\quad 2.77 \pm 0.11$ 


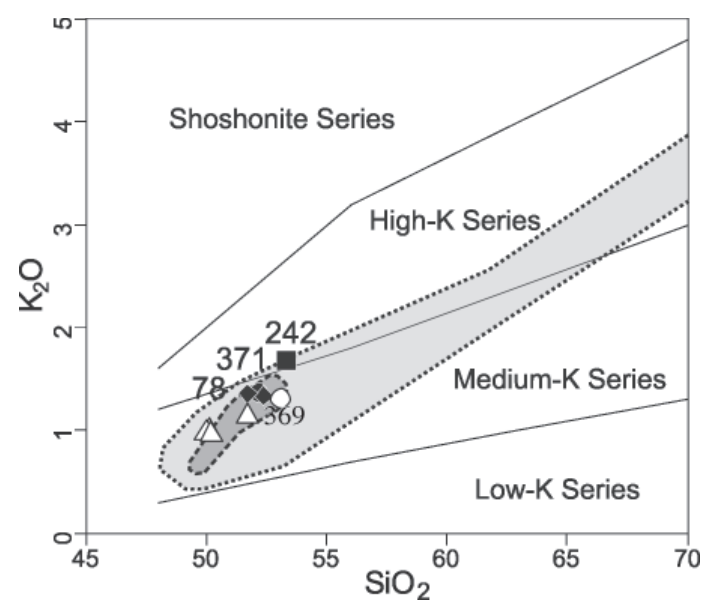

Fig. 12: $\mathrm{SiO} 2$ - K2O diagram (Peccerillo \& Taylor, 1976) for studied lavas. Symbols correspond to those in Fig. 10.

\section{CONCLUSIONS}

The origin of Metapán volcanic field is associated with the formation of the Ipala Graben and its lateral shoulder, the San Diego Fault. The opening of the Ipala Graben and its lateral shoulders is related to the boundary between two segments of the Central American Trench and to the migration of the Chortis block along the Median Trough and Motagua - Chamalecon fault systems to the east. There are no signs of recent seismic activity in this region, nevertheless with ongoing processes of subduction, the migration of the Chortis block and E-W extension of the Chortís block (Guzmán-Speziale, 2001 supposes a rate of $8 \mathrm{~mm} / \mathrm{yr}$ ), the Ipala Graben should continue in activity.

Volcanic activity represented by El Cóbano shield volcano initiated before the activation and principal movements of the San Diego Fault. Activity of San Diego fault would be dated with dating of El Cóbano Formation within the framework of further researches. Later activity of Pre-San Diego and San Diego Formations filled the tectonic valley of San Diego Fault. Chemical compositions are similar to those of the lavas from the Guatemalan part of the Ipala Graben and other BVF volcanic rocks in Central America.
BVF magmatism in the Metapán area persisted for a relatively long time, but there is no evidence for volcanic activity younger than Tierra Blanca Joven deposits (430 AD, Dull et al., 2001). Currently, the individual cinder cone zone of the Metapán volcanic field represents no real hazard for inhabitants, because:

a) There was no proved volcanic activity for at least 2,000 years, and

b) Lava fields are inhabited very scarcely.

Monogenetic cones producing magma of a relatively uniform composition characterize volcanic activity in the area of Metapán. No evidence for extensive magmatic differentiation was observed, arguing against a long-term magma storage in magmatic chambers (except of extinct El Cóbano shield volcano). Existing cones are extinct but new portion of primary magma would presumably create new ones. Such a scenario cannot be excluded in the tectonic setting of the Metapán area.

Volcanism in the Metapán area influenced the evolution of Güija and Metapán lakes. First, lavas of Loma Iguana probably separated the Metapán Lake from Güija Lake. The Metapán Lake is currently being divided into two parts by a fluvial delta progressing southward (Hradecký et al., 2005). Lavas of San Diego hacked off the

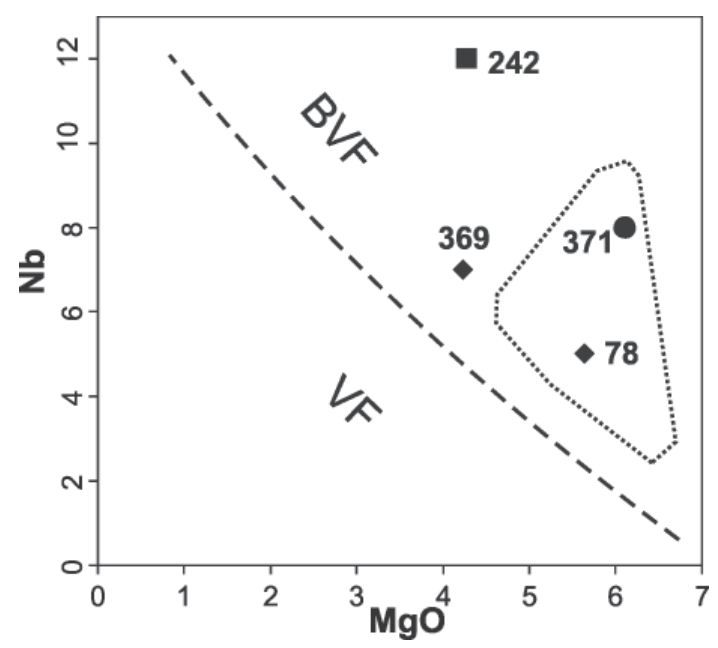

Fig. 13: $\mathrm{MgO}-\mathrm{Nb}$ diagram (after Walker et al., 2000) for lavas from Metapán volcanic field. Solid symbols correspond to those in Fig. 10, polygon delimits composition of BVF basalts from Cinotepeque range (after Rapprich \& Hradecký, 2005). 
original outlet of the Metapán Lake (see fluvial deposits north of San Diego volcano in Fig. 5.). The latest event was the damming of the Guiija Lake by the lava of Cerro Quemado, which shifted the confluence of the rivers Río Desagüe and Río Guajoyo some $4.5 \mathrm{~km}$ downstream and probably raised the water level of the Güija Lake.

\section{ACKNOWLEDGMENTS}

The geological research was financially supported by the Ministry of Foreign Affairs of the Czech Republic as a "Development assistance project" - focused on natural hazards. T. Vorel, P. Hradecký and I. Baroň - all from the Czech Geological Survey, gave us useful help during the field campaign. Thanks are given also to all analysts and technicians of the laboratories of the Czech Geological Survey, who carried out the chemical analyses and prepared set of thin sections. Z. Pécskay performed the radiometric dating in the K-Ar lab at the Institute of Nuclear Research of the Hungarian Academy of Science (ATOMKI). Present paper has been finalized within the framework of the Czech Science Foundation project No. 205-06-1811.

\section{REFERENCES}

BURKART, B. \& SELF, S., 1985: Extension and rotation of crustal blocks in northern Central America and effect on the volcanic arc.- Geology, 13: 22-26.

CARR, M.J., 1974: Tectonics of the Pacific margin of northern Central America.- 159 págs. Dartmouth College, Hanover, NH [PhD thesis].

CARR, M.J., 1976: Underthrusting and Quaternary faulting in northern Central America.- Geol. Soc. Am. Bull. 87: 825-829.

CARR, M. J., FEIGENSON, M. D., PATINO, L. C., AND WALKER, J. A., 2003: Volcanism and geochemistry in Central America:
Progress and Problems.- In: EILER, J.M.: Inside the Subduction Factory, Geophys. Monogr. Ser. 138, AGU, p. 153-174.

DENGO, G., BOHNENBERGER, O. \& BONIS, S., 1970: Tectonics and volcanism along the Pacific Marginal Zone of Central America.- Geol.- Rundschau, 59(3): 12151232.

DULL, R.A., SOUTHON, J.R., \& SHEETS, P., 2001: Volcanism, ecology and culture: A reassessment of the volcan Ilopango TBJ eruption in the Southern Maya Realm.Latin American Antiquity, 12(1): 25-44.

GUZMÁN-SPEZIALE, M., 2001: Active seismic deformation in the grabens of northern Central America and its relationship to the relative motion of the North AmericaCaribbean boundary.- Tectonophysics, 337: 39-51.

HRADECKÝ, P., BABŮREK, J., BARATOUX, L., BAROŇ, I., ČECH, S., HERNÁNDEZ, W., NOVÁK, Z., RAPPRICH, V., ŠEVČÍK, J. \& VOREL, T., 2005: Geologický výzkum prírodních rizik v severozápadním Salvadoru, v departmentu Santa Ana / Estudio geologico de los peligros naturales, area de Metapán, El Salvador (Geological research on natural hazards in NW El Salvador, area of Metapán, Santa Ana department - in Czech and Spanish).- 107 págs. Archive of CGS, Prague and SNET, San Salvador [unpublished report].

IRVINE, T.N. \& BARAGAR, W.R.A., 1971: A guide to the chemical classification of the common volcanic rocks.- Can. J. Earth. Sci. 8: 523-548.

JANOUŠEK, V., FARROW, C.M. \& ERBAN, V., 2006: Interpretation of whole-rock geochemical data in igneous geochemistry: Introducing Geochemical Data Toolkit (GCDkit).- J. Petrol., 47(6): 1255-1259. 
LeBAS,M.J.,LeMAITRE,R.W.,STRECKEISEN, A. \& ZANETTIN B., 1986: A chemical classification of volcanic rocks based on the total alkali-silica diagram.- J. Petrology, 27: 745-750.

MANN, P. - ed., BAUMGARTNER, P.O., BELLON, H., BORDELON, M.J., CARR, M.J., CHANNELL, J.E.T., COATES, A.G., COLLINS, L.S., COTTEN, J., De-BOER, J.Z., DEFANT, M.J., Di-MARCO, G., DRUMMOND, M.S., GALEWSKY, J., GUENDEL, F., HARDY, N.C., HEATH, R.P., JACKSON, J.B.C., KELLOGGVEGA, V., KIKUCHI, M., KOLARSKY, R.A., LEEMAN, W.P., MAURY, R.C., McINTOSH, K.D., McNALLY, K., MONECHI, S., MONTERO, W., MORRE, F., OBANDO, J.A., PROTTI, M., REED, D.L., SENDER, K.L., SILVER, E.A., SILVER, G.A., STEWART, R.H., TAJIMA, F., Von-HUENE, R. \& WESTBROOK, G.K., 1995: Geologic and Tectonic Development of the Caribbean Plate Boundary in Southern Central America.349 págs. Geol. Soc. Am. Spec. Paper 295, Boulder, CO.

MARTÍNEZ-DÍAZ, J.J., ÁLVAREZ-GÓMEZ, J.A., BENITO, B. \& HERNÁNDEZ, D., 2004: Triggering of destructive earthquakes in El Salvador.- Geology, 32(1): 65-68.

PATINO, L.C., CARR, M.J. \& FEIGENSON, M.D., 1997: Cross-arc geochemical variations in volcanic fields in Honduras C.A.: progressive changes in source with distance from the volcanic front.- Contrib. Mineral. Petrol. 129: 341-351.

PECCERILLO, R. \& TAYLOR, S.R., 1976: Geochemistry of Eocene calc-alkaline volcanic rocks from the Kastamonu area, Northern Turkey.- Contrib. Mineral. Petrol. 58: 63-81.
RAPPRICH, V. \& HRADECKÝ, P., 2005: The Cinotepeque Range of central El Salvador: Geology, magma origin and volcanism. Bull. Geosci. 80(4): 277-286.

SAPPER, K., 1937: Mittelamerika. Handbuch der Regionalen Geologie, C.- 160 págs. Winters Universtätsbuchhandlung, Heidelberg.

STOIBER, R.E. \& CARR, M.J., 1973: Quaternary tectonic and volcanic segmentation of Central America.- Bull. Volcanol. 37: 304-325.

WALKER, J.A., 1981: Petrogenesis of lavas from cinder cone fields behind the volcanic front of Central America.- J. Geol. 87: 721-739.

WALKER, J.A., CARR, M.J., PATINO, L.C., JOHNSON, C.M., FEIGENSON, M.D. \& WARD, R.L., 1995: Abrupt change in magma generation processes across the Central American arc in southern Guatemala: flux-dominated melting near the base of the wedge to decompression melting near the top of the wedge.Contrib. Mineral. Petrol. 120: 378-390.

WALKER, J.A., PATINO, L.C., CAMERON, B.I. \& CARR, M.J., 2000: Petrogenetic insights provided by compositional transects across the Central American arc.- J. Geophys. Res. 105: 18949-18963.

WEBER, H.S., 1979: On the lithology and stratigraphy of the „Estratos de Metapán“ in the Republic of El Salvador, Central America.- Geol. Jb. B 37: 31-54.

WEBER, H.S., WIESEMANN, G. \& WITTEKINDT, H., 1974: Mapa Geológico General de la República de El Salvador 1 : 500000 / Geologische Übersichtskarte der Republik El Salvador 1: 500000 (after geological maps 1: 100000 - 1967- 
71).- Bundesanstalt für Bodenforschung, Hannover.

WIESEMANN, G., WEBER, H.S., LORENZ, W. \& SCHMIDT-THOMÉ, M., 1978: Mapa geológico de Republica de El Salvador, escala 1:100 000.- Bundesanstalt für Geowissenschaften und Rohstoffe, Hannover.
WILLIAMS, H., McBIRNEY, A.R. \& DENGO, G., 1964: Geologic Reconnaissance of southeastern Guatemala.- Univ. Calif. Publ. Geol. Sci. 50: 1-62.

WILLIAMS, H. \& MEYER-ABICH, H., 1955: Volcanism in the southern part of El Salvador with particular reference to the collapse basins of Lakes Coatepeque and Ilopango.Univ. Calif. Publ. Geol. Sci. 32: 1-64. 